\title{
Profil Kemampuan Komunikasi Matematika dengan Pembelajaran Joyful Learning Berbasis Konteks Budaya Melayu
}

\author{
Della Amrina Yusra \\ Program Studi Pendidikan Matematika UIN Sulthan Thaha Saifuddin Jambi \\ E-mail: dellaamrinayusra@uinjambi.ac.id
}

\begin{abstract}
The research underlying this paper is descriptive qualitative research conducted through three stages, the pre-field stage, the stage of field-work, and the data analysis stage. The subjects in this study were six students of grade seven Islamic Junior High School or Madrasah Tsanawiyah Yaspi Labuhan Medan with two subjects capable of good mathematical communication, two subjects with sufficient communication skills, and two subjects with less communication skills. Subject selected through purposive sampling. Based on the research, were obtained: first, there is a positive change in the ability of students to communicate mathematics after being given joyful learning based on the context of Malay culture; second, the process of student answers shows that subjects are better able to communicate mathematical questions after being given joyful learning based on Malay cultural context. Furthermore, this research recommended that teachers can use joyful learning based on cultural contexts by presenting problems related to local culture as an alternativelearning.
\end{abstract}

Keywords: Mathematics communication; joyful learning; Malay culture.

\begin{abstract}
Abstrak: Penelitian yang melatari tulisan ini merupakan penelitian kualitatif deskriptif yang dilakukan melalui tiga tahap, yakni tahap pra-lapangan, tahap pekerjaan lapangan, dan tahap analisis data. Subjek dalam penelitian ini adalah enam siswa kelas VII MTs Yaspi Labuhan Medan dengan dua subjek berkemampuan komunikasi matematika baik, dua subjek berkemampuan komunikasi cukup, dan dua subjek berkemampuan komunikasi kurang, pemilihan subjek dilakukan dengan cara purposive sampling. Dari hasil penelitian yang dilakukan diperoleh: pertama, terdapat perubahan positif kemampuan siswa dalam mengkomunikasikan matematika setelah diberikan pembelajaran joyful learning berbasis konteks budaya Melayu; kedua, proses jawaban siswa menunjukkan subjek lebih bisa mengkomunikasikan soal matematika setelah diberikan pembelajaran joyful learning berbasis konteks budaya Melayu. Selanjutnya, disarankan agar guru dapat menggunakan pembelajaran joyful learning berbasis konteks budaya dengan menyajikan masalah yang berkaitan dengan budaya lokal sebagai alternatif pembelajaran.
\end{abstract}

Kata-kata kunci: komunikasi Matematika; Joyful Learning; Budaya Melayu. 


\section{Pendahuluan}

Dalam kegiatan pembelajaran matematika di sekolah, kemampuan belajar matematika sangat butuh perhatian, terutama kemampuan komunikasi matematika. Sejalan dengan pendapat Saragih ${ }^{1}$ perkembangan bidang teknologi komunikasi dan informasi yang sangat pesat sekarang ini, tidak terlepas dari perkembangan daya pikir manusia. Sebagai akibat dari kemajuan teknologi komunikasi dan informasi, arus informasi datang dari berbagai penjuru dunia secara cepat dan beragam. Dari kenyataan yang ditemukan di lapangan, pembelajaran matematika selama ini masih kurang memberikan perhatian terhadap pengembangan kemampuan komunikasi matematika, sehingga penguasaan kompetensi ini bagi siswa masih rendah. Untuk uji kemampuan komunikasi matematika awal siswa, peneliti memberikan tes tertulis berbentuk soal cerita kepada siswa.

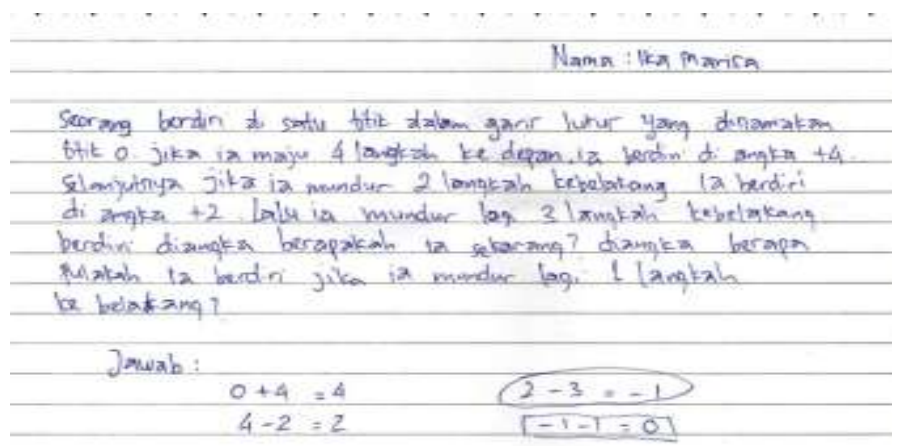

Gambar 1. Soal cerita dan jawaban siswa tahap awal

Dari jawaban siswa dapat terlihat bahwa siswa hanya menjawab pertanyaan langsung, tidak terarah dan sukar dipahami. Ketika diminta menjelaskan, siswa tidak dapat mengungkapkan metode ia mendapatkan jawaban itu. Siswa hanya melihat angka yang ada dan langsung menjumlahkan. Dari jawaban siswa tersebut juga dapat disimpulkan bahwa siswa tersebut memiliki kemampuan komunikasi matematika yang kurang dalam mengkomunikasikan jawaban. Permasalahan tersebut sejalan dengan permasalahan yang ditemukan oleh Yuliani dan Saragih ${ }^{2}$, disaat pembelajaran berlangsung siswa kesulitan untuk menyelesaikan soal-soal yang berhubungan dengan kehidupan sehari-hari yang memerlukan penggunaan matematika dan menyusunnya ke dalam sebuah model matematika. Hal ini dikarenakan soal yang diberikan selama ini tidak memuat soalsoal non rutin, sehingga tidak membuat siswa melakukan kegiatan refleksi, eksperimen, inkuiri, konjektur, dan generalisasi. Kesulitan yang dihadapi dapat dilihat dari bagaimana cara siswa berpikir secara kritis dalam menyelesaikan soal matematika yang diberikan. Hal yang sama juga diungkapkan oleh Saragih dan

1 Saragih, Sahat. "Pengaruh Pendekatan Pembelajaran dan Locus of Control terhadap Kemampuan Penalaran Matematika Siswa." Jurnal Kependidikan: Penelitian Inovasi Pembelajaran Vol. 41, No. 2, 2011

${ }^{2}$ Yuliani, Kiki, and Sahat Saragih. "The Development of Learning Devices Based Guided Discovery Model to Improve Understanding Concept and Critical Thinking Mathematically Ability of Students at Islamic Junior High School of Medan." Journal of education and practice, Vol.6, No.24, 2015 
Habeahan ${ }^{3}$ yaitu saat siswa dihadapkan pada soal-soal yang tidak rutin, contohnya soal cerita yang terkait pemecahan masalah yang berkaitan dengan kehidupan sehari-hari, nilai yang diperoleh oleh siswa biasanya akan lebih rendah jika dibandingkan dengan soal pilihan berganda.

Dari hasil pengamatan awal peneliti, peneliti menemukan siswa jenuh dan tidak fokus karena pelajaran monoton berpatok pada buku pelajaran,dan informasi yang diperolehtingkat motivasi belajar matematika siswa kelas VII MTs Yaspi Labuhan Deli Medan masih kurang. Untuk lebih mempertegas hasil observasi pengamatan awal peneliti memberikan angket motivasi belajar kepada 10 siswa secara acak, dapat dilihat dari 10 siswa 6 diantaranya memiliki tingkat motivasi kendah sekali. Dari pengamatan kemampuan motivasi awal ini maka perlu dirintis suatu penggunaan media pembelajaran matematika yang lebih disenangi dan mudah dipahami siswa agar tercipta kecintaan siswa terhadap pelajaran matematika. Salah satu cara untuk merintis pembelajaran yang dapat memotivasi siswa adalah dengan menggunakan pembelajaran berbasis budaya lokal (budaya Melayu) dan permainan tradisional. Sejalan dengan pendapat yang dikemukakan oleh Saragih dan Napitupulu4, yaitu siswa diharapkan untuk menggunakan matematika dan pola pikir matematika dalam kehidupan sehari-hari, dan untuk mempelajari berbagai jenis ilmu yang menekankan untuk pengaturan logis dan membangun karakter siswa serta juga kemampuan untuk menerapkan matematika. Jadi harapannya akan selalu dapat dikenang dan tidak menjemukan. Penggunaan pembelajaran berbasis budaya Melayu dan permainan tradisional tentunya akan menciptakan suasana baru yang menarik dan menyenangkan bagi siswa sehingga dapat menumbuhkan motivasi belajar bagi siswa.

Dari beberapa permasalahan di atas dan hasil dari observasi awal peneliti terhadap siswa kelas VII MTs Yaspi Labuhan Deli Medan, maka perlu dirintis pembelajaran matematika untuk membuang anggapan siswa yang negatif mengenai pelajaran matematika. Siswa membutuhkan hal yang bisa mengubah fikirannya dari matematika itu sulit menjadi matematika itu menyenangkan, salah satu pembelajaran yang cocok adalah pembelajaran joyful learning berbasis konteks budaya Melayu.

Berdasarkan permasalahan yang ditemukan peneliti di lapangan, maka rumusan masalah penelitian adalah bagaimana profil kemampuan komunikasi matematika dan motivasi belajar siswa dengan pembelajaran joyful learning berbasis konteks budaya Melayu. Penelitian ini dilakukan di MTs Yaspi Labuhan Deli Medan semester I tahun akademik 2015/2016. Penelitian ini menggunakan metode kualitatif deskriptif, dengan tiga tahapan yaitu tahap pra-lapangan, tahap pekerjaan lapangan dan tahap analisis data. Teknik pengambilan subjek dalam penelitian ini menggunakan teknik purposive sampling. Sebelum melakukan pemilihan subjek secara signifikan terlebih dahulu peneliti melakukan pemberian tes pemilihan subjek di kelas VII B MTs Yaspi Labuhan Deli Medan berupa 2 soal

${ }^{3}$ Saragih, Sahat, and Winmery L. Habeahan. "The improving of problem solving ability and students' creativity mathematical by using problem based learning in SMP Negeri 2 Siantar." Journal of Education and Practice, Vol.5 No.35. 2014

${ }^{4}$ Saragih, Sahat, and Elvis Napitupulu. "Developing Student-Centered Learning Model to Improve High Order Mathematical Thinking Ability." International Education Studies, Vol.8 No.6. 2015 
cerita untuk mengetahui kemampuan komunikasi matematika awal secara klasikal, dan pemberian angket motivasi belajar matematika siswa sebelum mendapat perlakuan pembelajaran joyful learning berbasis konteks budaya Melayu untuk mengetahui motivasi belajar matematika siswa.

Tes pemilihan subjek diberikan kepada siswa kelas VII B yang berjumlah 50 siswa. Pemberian tes ini bertujuan untuk menentukan subjek penelitian, siswa tersebut memiliki tingkat kemampuan baik, cukup atau kurang. Dari hasil tes yang dilakukan, terdapat 6 siswa yang memiliki kemampuan baik, 8 siswa yang memiliki kemampuan cukup, dan 36 yang memiliki kemampuan kurang.

Alat ukur yang digunakan berupa tes kemampuan komunikasi matematika siswa yang berguna untuk menentukan peringkat siswa. Jika salah satu kriteria tidak terpenuhi maka tingkatan siswa turun pada tingkat di bawahnya. Alat ukur yang digunakan adalah rubric kemampuan komunikasi. Rubrik penilaian kemampuan komunikasi tulis dapat dikatakan bahwa siswa yang memiliki nilai 3 mempunyai kemampuan komunikasi tulis baik, nilai 2 mempunyai kemampuan komunikasi tulis cukup, dan 1 mempunyai kemampuan komunikasi tulis kurang.

Dalam hal ini peneliti memilih 2 siswa pada tiap kriteria pemilihan subjek berdasarkan tingkat kemampuan komunikasi matematika yang memiliki masalah agar lebih terdeskripsi profil kemampuan komunikasi matematika. Dengan 2 subjek yang ditentukan pada tiap tingkat kemampuan komunikasi matematika, maka peneliti lebih mudah dalam menganalisis permasalahan yang sebenarnya terjadi pada subjek dengan membandingkan dan menyimpulkan hal-hal yang dianggap merupakan masalah pokok yang sebenarnya terjadi. Maka total subjek yang akan diteliti adalah 6 siswa dengan rincian 2 siswa yang memiliki kemampuan komunikasi baik, 2 siswa yang memiliki kemampuan komunikasi cukup, dan 2 orang siswa yang memiliki kemampuan komunikasi kurang.

Dalam pelaksanaan penelitian, prosedur pengumpulan data yang dilakukan adalah: (1) Pencarian subjek dengan pemberian 2 soal tes kemampuan komunikasi; (2) Pemberian angket motivasi belajar kepada siswa; (3) Peneliti memberikan pembelajaran joyful learning berbasis konteks budaya Melayu kepada subjek;(4) Peneliti memberi kesempatan kepada subjek untuk menyelesaikan LAS; (5) Peneliti mencatat kegiatan siswa selama menyelesaikan LAS; (6)Setelah subjek menyelesaikan LAS, peneliti melakukan wawancara untuk mengungkap profil kemampuan komunikasi matematika; (7) Setelah data terkumpul, selanjutnya dilakukan pengecekan keabsahan data dengan triangulasi sumber yaitu mencari kesesuaian data yang bersumber dari hasil LAS, angket dan wawancara yang dilakukan. Apabila data LAS kedua dan wawancara kedua yang triangulasi dengan data lembar LAS pertama dan wawancara yang pertama menunjukkan kesamaan, maka kedua data tersebut dikatakan valid dan reliabel. Proses seperti ini berlangsung terus sampai ditemukan data yang valid. 


\section{Komunikasi Matematika dan Joyful Learning}

Menurut Saragih ${ }^{5}$ Komunikasi secara umum dapat diartikan sebagai suatu peristiwa saling menyampaikan informasi atau pesan yang berlangsung dalam suatu komunitas. Dalam kegiatan belajar mengajar di kelas akan selalu terjadi komunikasi antara siswa dan guru, siswa sebagai pusat pembelajaran dan guru sebagai fasilitator. Keberhasilan program pembelajaran salah satunya dipengaruhi oleh bentuk komunikasi yang digunakan guru pada saat berinteraksi dengan siswa. Sedangkan menurut Guerreiro dan Serrazin ${ }^{6}$ komunikasi matematika merupakan alat bantu dalam transmisi pengetahuan matematika atau sebagai pondasi dalam membangun pengetahuan matematika. Dalam hal ini berarti kemampuan komunikasi matematika dapat diartikan sebagai kemampuan seseorang untuk pengungkapan ide-ide matematika dengan simbol, tabel, diagram, atau media lain untuk memperjelas masalah matematika dan disampaikan dengan bahasa matematika dalam kegiatan belajar mengajar matematika, dan dapat membantu guru memahami kemampuan siswa dalam menginterpretasikan dan mengekspresikan pemahamannya tentang konsep dan proses matematika yang mereka pelajari. Maka dapat disimpulkan bahwa kemampuan komunikasi matematika adalah kemampuan seseorang untuk pengungkapan ide-ide matematika dengan simbol, tabel, diagram, atau media lain untuk memperjelas masalah matematika dan disampaikan dengan bahasa matematika dalam kegiatan belajar mengajar matematika, dan dapat membantu guru memahami kemampuan siswa dalam menginterpretasikan dan mengekspresikan pemahamannya tentang konsep dan proses matematika yang mereka pelajari.

Menurut pendapat Singh $^{7}$ pembelajaran yang menyenangkan (joyful learning) adalah jenis pengalaman yang bisa membuat peserta didik merasakan kenikmatan dalam proses belajar pembelajaran. Sebuah lingkungan belajar yang sesuai dengan urutan belajar yang tepat sangat penting untuk belajar, terutama untuk anak-anak yang masih dalam masa perkembangan awal. Menurut Mulyasa ${ }^{8}$ pembelajaran menyenangkan merupakan suatu proses pembelajaran yang didalamnya terdapat sebuah kohesi yang kuat antara pendidikan dan peserta didik, tanpa ada perasaan terpaksa atau tertekan (not under pressure). Pendidikan merupakan pembentukan karakter bangsa yang sudah menjadi wacana universal selama ini. Di era yang kompetitif ini peserta didik tidak hanya diharapkan memiliki pengetahuan melainkan juga memiliki penghayatan terhadap nilai-nilai pengetahuan, seperti penanaman unsur-unsur budaya pada peserta didik karena pendidikan dan kebudayaan merupakan satu kesatuan yang tidak dapat dihindari dari kehidupan sehari-hari. Hal tersebut sejalan dengan yang dikemukakan oleh

\footnotetext{
${ }^{5}$ Saragih, Sahat. "Peningkatan Kemampuan Komunikasi Matematis Siswa SMA/MA di Kecamatan Simpang Ulim melalui Model Pembelajaran Kooperatif Tipe STAD." Jurnal Pendidikan dan Kebudayaan Vol.19 No.2. 2013

${ }^{6}$ Guerreiro, António, and Lurdes Serrazina. "Communication as social interaction primary school teacher practices." Working Group. Vol. 10. 2009.

${ }^{7}$ Singh, Seema. "Creating a joyful learning environment at primary level." Shaikshik Parisamvad (An International Journal of Education) Vol.4 No.1. 2014

${ }^{8}$ Mulyasa, Enco. "Menjadi guru profesional menciptakan pembelajaran kreatif dan menyenangkan." Bandung: Remaja Rosdakarya. 2005
} 
Wahyuni, dkk ${ }^{9}$ yaitu budaya merupakan kesatuan yang utuh dan menyeluruh, berlaku dalam suatu masyarakat dan pendidikan merupakan kebutuhan mendasar bagi setiap individu dalam masyarakat.

\section{Proses Pengerjaan Lembar Aktifitas Siswa (LAS) dalam Kegiatan Pembelajaran Joyful Learning Berbasis Konteks Budaya Melayu}

Kegiatan ini diawali dengan pemberian LAS kegiatan awal berupa pengamatan gambar, pada kegiatan awal ini siswa diberi lembar kerja dengan perintah siswa membuat sebuah garis bilangan dari gambar masjid Al-Mashun (Masjid Kerajaan Melayu Kesultanan Deli Medan) dan diberikan alasan dengan apa yang mereka kerjakan. Berikut adalah salah satu jawaban LAS pada kegiatan awal:
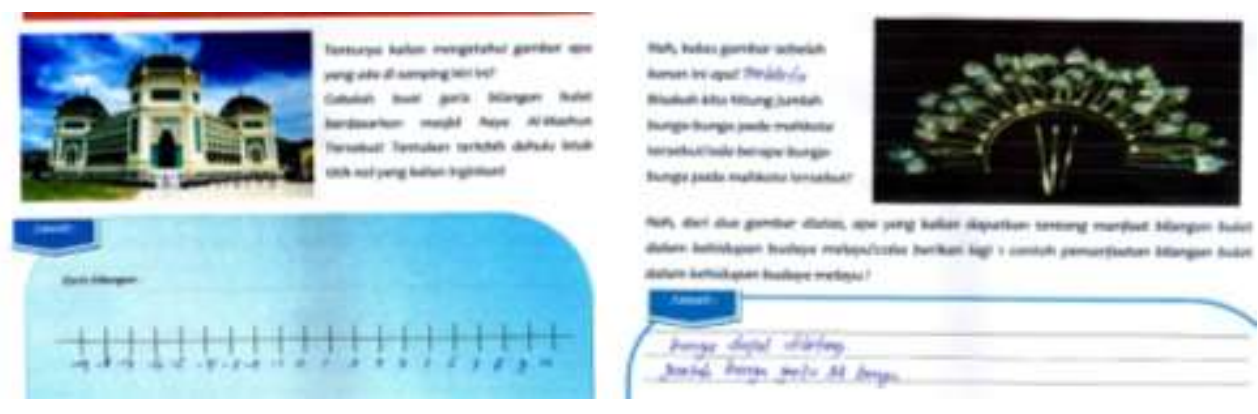

Gambar 2(a) Jawaban SKBMK2 Soal 1; 2(b) Jawaban SKBMK Soal 2

Dari gambar 2 (a) dapat terlihat bahwa siswa pada kelompok SKBMK2 dapat membuat garis bilangan sesuai dengan perintah soal, tetapi belum dapat menuliskan penjelasan berbentuk kata-kata, dan hanya mencoret (membuat garis) pada gambar pada soal. Dalam hal ini subjek mampu mengubah kata-kata kedalam bentuk gambar, tetapi belum bisa menjelaskan gambar kedalam bentuk kata-kata. Dari gambar terlihat bahwa subjek dapat mengkomunikasikan matematika tetapi belum sepenuhnya memenuhi kebutuhan indikator yang dibuat. Gambar 2 (b) siswa pada kelompok SKBMK2 menjawab bahwa bunga pada mahkota yang biasa digunakan pada mempelai wanita pada saat pernikahan dapat dihitung yaitu 38 bunga. Dalam soal kedua ini subjek dapat melakukan perhitungan pada mahkota, tetapi tidak dapat menuliskan contoh manfaat bilangan bulat dengan budaya karena pengetahuannya tentang kebudayaan Melayu hanya sedikit.

Setelah pemberian LAS pada kegiatan awal, Siswa dibentuk menjadi 10 kelompok dengan tiap kelompok berjumlah 5 orang dengan nama kelompok diberikan adalah nama-nama sultan kerajaan Maimun. Siswa pada setiap kelompok diberikan LAS 1 terkait dengan pembelajaran untuk menemukan konsep bilangan bulat (dengan konsep bilangan negatif sebelah kiri nol, dan bilangan positif sebelah kanan nol), pada LAS 1 diberikan petunjuk dan contoh untuk menelukan konsep seperti yang terlihat pada gambar 4 .

\footnotetext{
${ }^{9}$ Wahyuni, Astri, Ayu Aji Wedaring Tias, and Budiman Sani. "Peran etnomatematika dalam membangun karakter bangsa." Makalah Seminar Nasional Matematika dan Pendidikan Matematika, Prosiding, Jurusan Pendidikan Matematika FMIPA UNY, Yogyakarta: UNY. 2013
} 


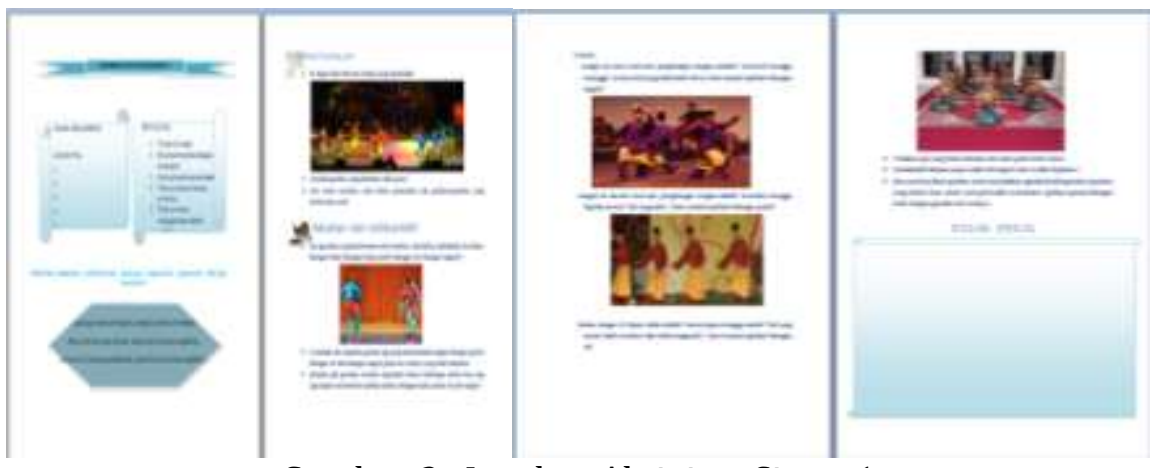

Gambar 3. Lembar Aktivitas Siswa 1

LAS 1 ini dilakukan secara berkelompok dengan memperhatikan video tari Melayu, setiap kelompok mengamati video menjawab pertanyaan-pertanyaan pada LAS 1 dan mengikuti perintah dan contoh yang telah diberikan.

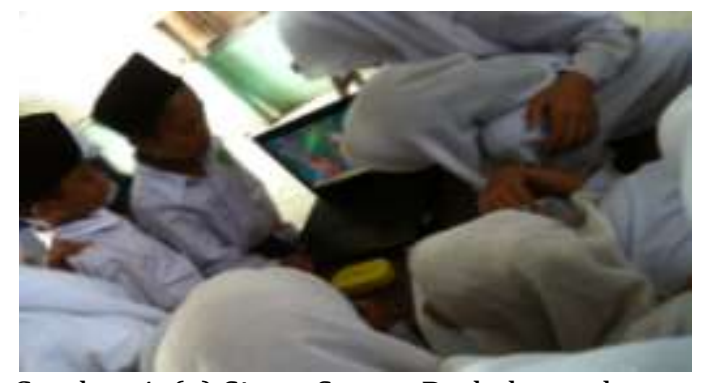

Gambar 4. (a) Siswa Secara Berkelompok Mengamati Video Tari Melayu;

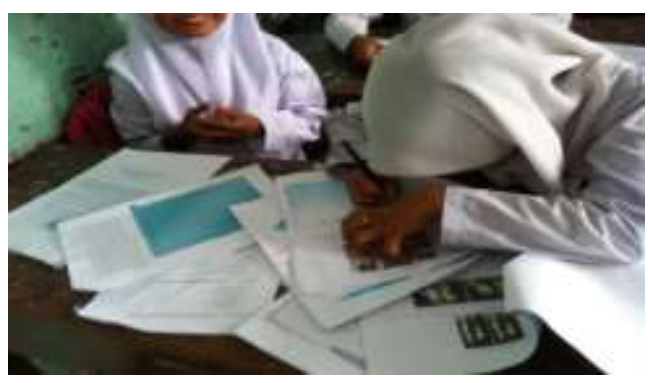

(b) Siswa Secara Individu Menuliskan Gerakan Tarian Untuk Konsep

Bilangan Bulat Positif, Negatif dan Nol

Pada pengerjaan LAS 1 siswa sangat senang dan antusias karena mereka dapat belajar menemukan konsep sendiri dan dengan cara yang belum pernah mereka rasakan sebelum ini, ada berbagai variasi jawaban nama gerakan tarian yang mereka buat sendiri dan pada proses penyelesaian secara keseluruhan siswa mengerti dan paham menemukan konsep letak bilangan bulat dengan gerakan tarian yang mereka perhatikan pada video yang mereka amati. Setelah LAS 1 selesai maka dilanjutkan pemberian LAS 2 dengan tujuan aplikasi penjumlahan bilangan bulat, siswa diminta membuat gerakan tarian dan menuliskan keterangan makna gerakan yang telah mereka buat.

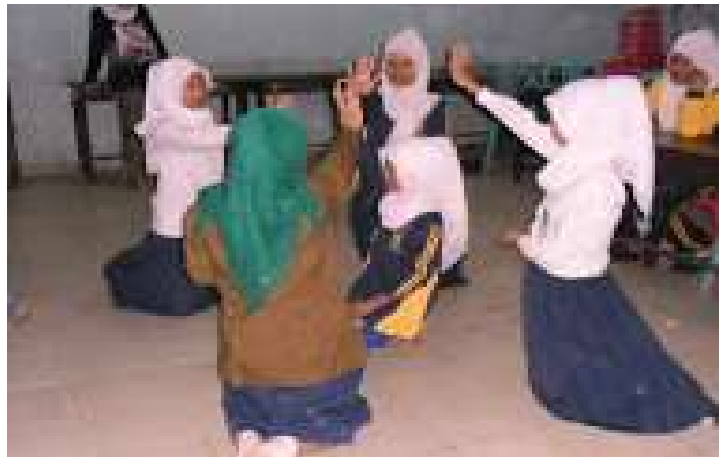

Gambar 5. (a) Siswa Secara Berkelompok Membuat Gerakan Tarian;

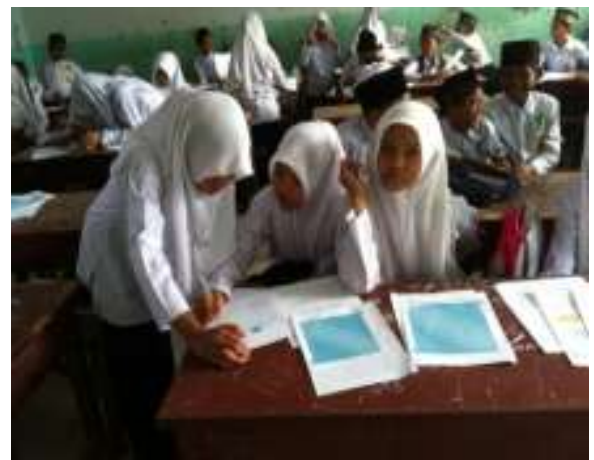

(b) Siswa Berdiskisi Menyelesaikan LAS 2 
Pada pengerjaan LAS 2 siswa membuat gerakan tarian secara berkelompok dan siswa senang karena dibebaskan membuat gerakan tarian apa saja untuk menjawab pertanyaan penjumlahan, setelah menari bebas siswa mengisi lembar LAS menjawab pertanyaan beupa beberapa soal cerita, dengan perintah siswa menjawab dengan cara langsung menjawab dengan perhitungan matematika dan dengan perhitungan dengan gerakan tarian, semua kelompok mampu menyelesaikan LAS 2 dengan baik, melakukan kegiatan pembelajaran sesuai dengan petunjuk dan perintah yang diberikan. Contoh jawaban siswa untuk $2+(-4)$ adalah " pertama-tama lakukan 2 langkah silang ke kanan, karena di tambah dengan negatif maka lakukan lagi 2 langkah silang ke kiri berarti pada posisi nol, dan 2 langkah silang ke kiri lagi berada pada posisi -2. Maka jawabannya adalah -2". Siswa sangat antusias dan bahagia dalam menyelesaikan LAS ini, siswa yang tadinya cenderung pasif menjadi aktif dan dapat mengekspos imajinasinya. Setelah selesai menyelesaikan LAS 2 maka siswa diberikan LAS 3 yaitu bermain bola bekel matematika.
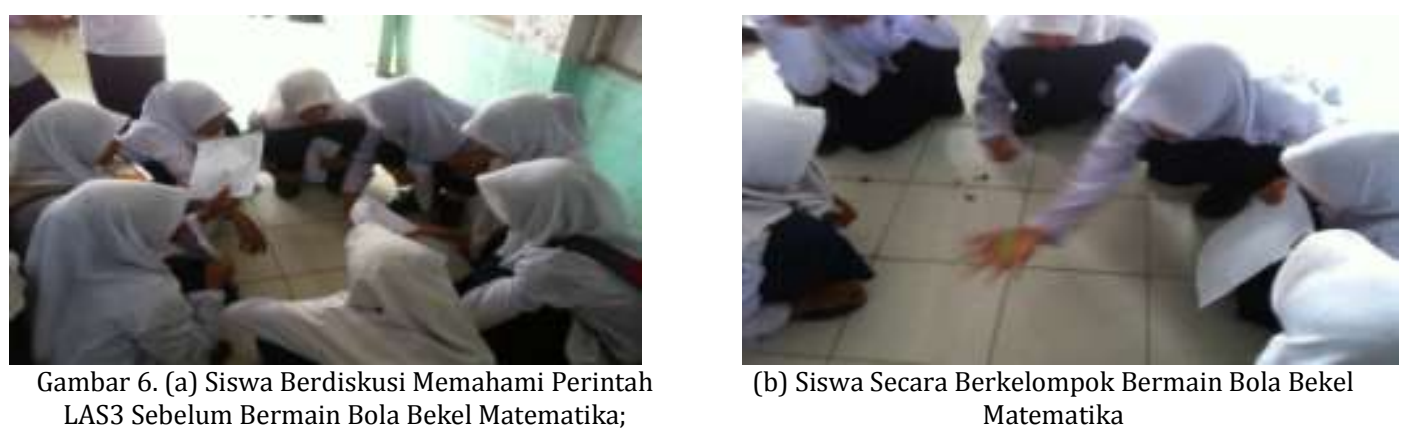
Matematika

Pembelajaran matematika biasa yang dihadapi siswa, tidak pernah dilakukan pembelajaran yang mengaplikasikan permainan tradisional hanya berfokus pada menyelesaikan soal dengan rumus-rumus sehingga siswa cenderung tegang dan bosan. Kegiatan ini yaitu bermain bola bekel matematika berguna untuk memperkuat konsep penjumlahan, siswa yang sudah kenal permainan ini sangat antusias dan semangat baik laki-laki maupun perempuan mereka bermain, terdapat keceriaan pada saat permainan berlangsung siswa sering tertawa-tawa karena harus membuat pantun atau pepatah Melayu sehingga terdapat kesan kegembiraan mereka dalam belajar matematika.

Untuk kegiatan materi pengurangan bilangan bulat siswa diberikan LAS 4 yang dikerjakan secara berkelompok.LAS ini diberikan untuk mengetahui kemampuan komunikasi siswa dalam penyelesaian masalah pengurangan bilangan bulat dengan menggunakan tutup botol bilangan. Di dalam LAS diberikan contoh dan cara melakukan pengurangan dengan menggunakan tutup botol bilangan, siswa perindividu di dalam kelompoknya diberikan kesempatan untuk memahami 1 contoh soal sendiri kemudian menjelaskan kepada teman kelompoknya secara bergantian ataupun mengerjakan secara bersama-sama.

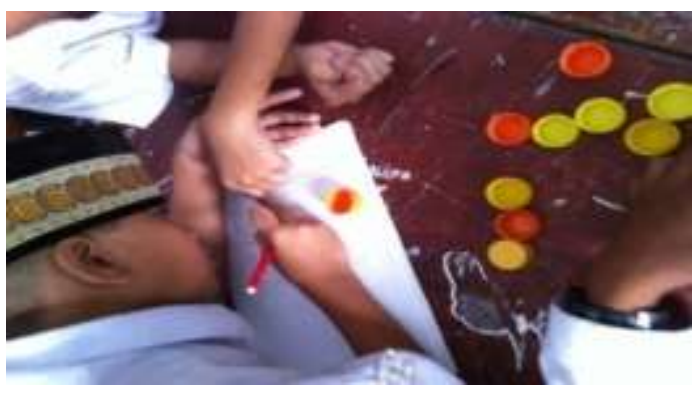

Gambar 7. (a) Siswa Menuliskan Hasil Perngurangan Dengan Tubo Bilangan;

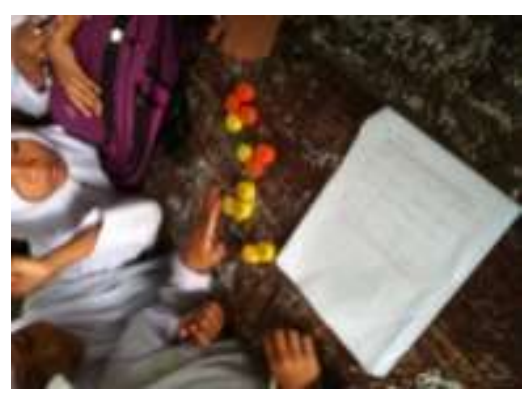

(b) Siswa Melakukan Perhitungan dengan Tubo Bilangan 
Dalam kegiatan ini dalam catatan lapangan peneliti siswa antusias, semangat dan terpanjar kesenangan dari tiap siswa dalam mengerjakan LAS serta aktif dalam penyelesaian soal. Setelah siswa secara kelompok telah menyelesaikan LAS, diberi kesempatan kepada kelompok untuk mempresentasikan di depan, dan kelompok lain dipersilahkan untuk mengomentari jika terjadi kesalahan langkah jawaban kepada kelompok yang presentasi. Setelah menyelesaikan LAS pengurangan bilangan bulat siswa diajak bermain dengan kelompoknya dengan permainan "ya oma" yaitu permainan tradisional yang biasa dimainkan oleh anak-anak suku Melayu, pada permainan ini siswa secara berkelompok terlebih dahulu menyiapkan soal yang akan diberikan kepada lawan. Permainan ini berlangsung seru dan menjadi pengalaman baru bagi siswa.

Hasil analisis selama proses pembelajaran berupa pembelajaran joyful learning berbasis konteks budaya Melayu siswa lebih aktif bertanya dan mempunyai tingkat berpikir lebih tinggi sehingga mereka mampu mengkomunikasikan melalui tulisan dan terutama secara lisan. Berdasarkan analisis jawaban LAS dan wawancara mendalam terhadap keenam subjek, secara keseluruhan siswa merasa terbantu dan senang dengan perangkat pembelajaran joyful learning berbasis konteks budaya Melayu. Siswa menjadi lebih mengenal kebudayaan Melayu yang merupakan budaya lokal di MTs Yaspi Labuhan Deli Medan, dan siswa menjadi lebih bisa mengaitkan lingkungan, sejarah, permainan tradisional, adat dan kebiasaan masyarakat melayu dengan pembelajaran matematika. Sehingga disimpulkan bahwa komponen perangkat pembelajaran yang dibuat berdasarkan pembelajaran joyful learning berbasis konteks budaya Melayu berkontribusi positif terhadap kegiatan pembelajaran matematika siswa.

Hal ini sejalan dengan hasil penelitian yang dilakukan oleh Nyoman ${ }^{10}$ dalam penelitiannya tentang pembelajaran berbasis budaya lokal yaitu berdasarkan hasil penelitian dan pembahasannya, pembelajaran inkuiri terbimbing berbasis budaya lokal efektif meningkatkan keterampilan berpikir tingkat tinggi siswa. Guru dapat menerapkan pembelajaran pembelajaran berbasis budaya lokal sebagai alternatif untuk meningkatkan keterampilan berpikir tingkat tinggi siswa. Sehingga dapat disimpulkan bahwa proses jawaban siswa yang memperoleh pembelajaran dengan pembelajaran joyful learning berbasis konteks budaya Melayu lebih baik dalam menyelesaikan soal-soal kemampuan komunikasi matematika.

\section{Profil Proses Jawaban Kemampuan Komunikasi Matematika dengan Pembelajaran Joyful Learning Berbasis Konteks Budaya Melayu}

Untuk mengetahui kemampuan komunikasi matematika subjek setelah diberikan pembelajaran joyful learning berbasis konteks budaya Melayu, peneliti memberi 4 soal tes kemampuan komunikasi matematika kepada keenam subjek untuk mengetahui proses jawaban tes kemampuan komunikasi matematika, dengan cara

10 Nyoman, S. "Pembelajaran Inkuiri Terbimbing Berbasis Budaya Lokal Untk Meningkatkan Keterampilan Berpikir Kritis Siswa SMA Negeri 4 Singaraja”. Bali: Seminar Nasional Riset Inovatif I Bali. 2013 
4 soal diletakkan di meja yang berbeda dan subjek harus membaca pantun Melayu atau pepatah Melayu sebelum menuju tiap meja soal, jadi subjek harus menyiapkan 4 pantun atau pepatah Melayu sebelum dilakukan tes kemampuan komunikasi matematika.

Dari hasil analisis proses jawaban tes kemampuan komunikasi matematika dan hasil wawancara terhadap keenam subjek dapat disimpulkan bahwa dalam melakukan penyelesaian soal,terdapat perubahan positif padasiswa pada kelompok SKKMB, selama kegiatan pembelajaranlebih aktif dan komunikatif, serta dalam menyelesaikan tes kemampuan komunikasi siswa pada kelompok SKKMB mampu mengkomunikasikan jawaban dalam bentuk tulisan dengan jauh lebih baik dari sebelum mendapatkan pembelajaran joyful learning berbasis konteks budaya Melayu dan motivasi belajarnya semakin menjadi lebih baik. Untuksiswa pada kelompok SKCMK juga terdapat perubahan positif dan menjadi lebih aktif dan imajinatif dalam proses kegiatan belajar dan mengajar, dalam menyelesaikan tes kemampuan komunikasisiswa pada kelompok SKCMK mampu menuliskan jawaban dengan baik dan terlihat bahwa kemampuan komunikasinya terdapat kemajuan yang baik dan motivasi belajarnya menjadi sangat baik.Siswa pada kelompok SKBMK yang memang telah mempunyai kemampuan komunikasi baik menjadi semakin baik dengan pembelajaran ini, dan dalam mengerjakan tes kemampuan komunikasi mampu menyelesaikan dengan baik dan bervariatif, yang paling tampak adalah motivasi belajarnya sangat berubah positif menjadi sangat baik karena mereka senang dengan pembelajaran ini. Secara umum sebagian siswa telah mampu menjelaskan pengerjaan soal dengan mengkomunikasikan permasalahan matematika ke dalam bentuk tulisan, yang ditunjukkan oleh proses jawaban yang sudah sesuai dengan indikator kemampuan komunikasi matematika dengan menuliskan penyelesaian jawaban secara jelas dan benar, mengubah permasalahan ke kalimat matematika yang benar, melakukan perhitungan yang jelas dan benar, dan menggunakan simbol atau tanda matematika yang sesuai. Hal ini disebabkan karena proses pelaksanaan tes kemampuan komunikasi matematika dengan menggunakan pembelajaran joyful learning berbasis konteks budaya Melayu, yang menuntut siswa untuk lebih banyak berpikir eksploratif daripada sekedar berpikir mekanis dan prosedural. Permasalahan yang diberikan merupakan permasalahan yang sering dialami oleh subjek sehingga ide dan imajinasi dapat tereksplorasi dalam mengkomunikasikan matematika.

Adapun hasil penelitian pembelajaran berbasis budaya yaitu penelitian oleh Sasono ${ }^{11}$ yaitu berdasarkan hasil analisis dari siklus I, II dan III yang terdiri dari 4 LKS. Hasil belajar siswa yang menggunakan perangkat pembelajaran yang berupa LKS dengan berorientasi pada budaya lokal mengalami peningkatan. Dalam hal ini pembelajaran berbasis budaya dapat meningkatkan keterampilan proses siswa. Sehingga dapat disimpulkan bahwa pemberian pembelajaran joyful learning berbasis konteks budaya Melayu dapat memberikan hal positif dengan siswa lebih memiliki kemampuan komunikasi matematika dari sebelum dilakukan pembelajaran joyful learning berbasis konteks budaya dan siswa lebih terampil dalam mengkomunikasikan matematika dalam proses jawaban, dengan

${ }^{11}$ Sasono, M. "Pengembangan Strategi Pembelajaran Sains Terpadu Berbasis Budaya Lokal Untuk Meningkatkan Keterampilan Proses Siswa Di SMP Negeri 3 Melati" Yogyakarta: Jurnal Pendidikan MIPA UNY, Vol.2, No. 1. 2010 
memberikan masalah yang sering dialami siswa, maka pola pikir siswapun tidak hanya terbatas pada buku teks, sehingga siswa mampu menjelaskan tentang proses penyelesaian masalah yang ditulis jelas dan benar, siswa juga menjadi mampu mengubah masalah kekalimat matematika dengan benar dan siswa mampu melakukan perhitungan dengan benar, mereka dapat menyelesaikan permasalahan dengan cara mereka sendiri dan langkah-langkah penyelesaian yang mereka anggap tepat. Sehingga hal tersebut berdampak pada hasil tes kemampuan komunikasi matematika siswa, dimana kebanyakan jawaban siswa sistematis, terstruktur, bervariasi, dan sesuai dengan indikator kemampuan komunikasi matematika siswa. Berbeda dengan pembelajaran biasa, siswa hanya dituntut untuk menjawab soal dengan benar seperti yang dicontohkan guru.

\section{Penutup}

Berdasarkan hasil analisis dan pembahasan dalam penelitian ini, dikemukakan beberapa kesimpulan sebagai berikut: (1) Pembelajaran menggunakan joyful learning berbasis konteks budaya Melayu dapat membantu siswa menemukan konsep matematika secara mandiri dengan suasana yang mereka senangi, dapat membuat mereka lebih aktif bertanya serta memiliki kemampuan berpikir lebih imajinatif dan bervariatif dalam menyelesaikan masalah matematika yang membuat mereka lebih mampu mengkomunikasikan matematika lebih baik; (2) proses jawaban siswa pada tes kemampuan komunikasi matematika setelah dilakukan pembelajaran joyful learning berbasis konteks budaya Melayu mengalami perubahan positif dan jawaban siswa lebih menunjukkan kemampuan komunikasi dalam menyelesaikan permasalahan matematika yang diberikan, Subjek lebih bisa menjelaskan tentang proses penyelesaian masalah yang ditulis secara benar dan jelas, bisa mengubah masalah ke kalimat matematika yang benar, dan melakukan perhitungan dengan lebih hati-hati hingga menghasilkan perhitungan yang jelas dan benar. Pembelajaran ini juga dapat mengaktifkan siswa dengan menemukan konsep penjumlahan dan pengurangan bilangan bulat secara mandiri, selain itu juga dapat membuat subjek lebih mengenal budaya Melayu dan bisa mengaplikasikan permainan tradisional Melayu dengan pembelajaran matematika;

\section{Bibliografi}

Guerreiro, António, and Lurdes Serrazina. "Communication as social interaction primary school teacher practices." Working Group, Vol. 10, 2009.

Nyoman, S. "Pembelajaran Inkuiri Terbimbing Berbasis Budaya Lokal Untk Meningkatkan Keterampilan Berpikir Kritis Siswa SMA Negeri 4 Singaraja”. Bali: Seminar Nasional Riset Inovatif I Bali, 2013.

Mulyasa, Enco. Menjadi guru profesional menciptakan pembelajaran kreatif dan menyenangkan, Bandung: Remaja Rosdakarya, 2005. 
Saragih, Sahat. "Pengaruh Pendekatan Pembelajaran dan Locus of Control terhadap Kemampuan Penalaran Matematika Siswa."Jurnal Kependidikan: Penelitian Inovasi Pembelajaran, Vol. 41, No.2, 2011.

Saragih, Sahat. "Peningkatan Kemampuan Komunikasi Matematis Siswa SMA/MA di Kecamatan Simpang Ulim melalui Model Pembelajaran Kooperatif Tipe STAD." Jurnal Pendidikan dan Kebudayaan, Vol. 19, No. 2, 2013.

Saragih, Sahat, and Winmery L. Habeahan. "The improving of problem solving ability and students' creativity mathematical by using problem based learning in SMP Negeri 2 Siantar." Journal of Education and Practice Vol.5 No.35. 2014.

Saragih, Sahat, and Elvis Napitupulu. "Developing Student-Centered Learning Model to Improve High Order Mathematical Thinking Ability." International Education Studies, Vol. 8, No. 6, 2015.

Sasono, M. "Pengembangan Strategi Pembelajaran Sains Terpadu Berbasis Budaya Lokal Untuk Meningkatkan Keterampilan Proses Siswa Di SMP Negeri 3 Melati", Jurnal Pendidikan MIPA UNY, Vol. 2, No. 1. 2010.

Singh, Seema. "Creating a joyful learning environment at primary level." Shaikshik Parisamvad (An International Journal of Education), Vol. 4 No. 1, 2014.

Wahyuni, Astri, Ayu Aji Wedaring Tias, and Budiman Sani. "Peran etnomatematika dalam membangun karakter bangsa." Makalah Seminar Nasional Matematika dan Pendidikan Matematika, Prosiding, Jurusan Pendidikan Matematika FMIPA UNY, Yogyakarta: UNY. 2013.

Yuliani, Kiki, and Sahat Saragih. "The Development of Learning Devices Based Guided Discovery Model to Improve Understanding Concept and Critical Thinking Mathematically Ability of Students at Islamic Junior High School of Medan." Journal of education and practice, Vol. 6, No. 24, 2015. 